\title{
A Task Force on Overseas Selection
}

\author{
by David Matas
}

At its November 1988 General Meeting in Montreal, the Canadian Council for Refugees decided to establish both a working group and a task force on the overseas protection of refugees. The creation and administration of the task force became the first and most important assignment of the working group.

Since its inception, the working group has met twice. Once in Toronto, in April, 1989 and a second time in Vancouver in June. At both meetings the task force monopolized the discussions of the working group.

The terms of reference are to focus on overseas selection of refugees only. The working group is excluding any consideration of the inland refugee determination process. As well, for overseas selection, the working group is asking the task force to look at refugee claimants only. It is excluding an examination of the overseas processing for immigrants who wish to come to Canada for economic or family reasons.

The only exception to the limitation is family abroad wishing to join refugees or refugee claimants in Canada. Though the family abroad may not, separate from their relatives in Canada, be part of the refugee stream, there is an obvious refugee dimension once there is an attempt to unify a refugee family.

It is the view of the working group that the task force should examine both government sponsorship and private sponsorship of refugees. The Canadian Council for Refugees is an organization that groups together those involved in private sponsorship. Yet the Council is, inevitably, interested in who the Government sponsors, or, more accurately, who the Government does not sponsor. Who the Government does not sponsor has a direct bearing on who the private sector will try to sponsor.

The refugee selection system overseas includes persons in a number of designated classes who are not technically refugees. People from the self-exiled class, from Eastern Europe, and the Indochinese designated class, are eligible for entry to Canada provided only they are outside their home country and can successfully establish themselves. People in these two classes do not have to meet the refugee definition. People in the political prisoners and oppressed persons class cannot, by the very way the class is defined, meet the refugee definition. The class covers political prisoners and oppressed persons in their home country. Refugees, by definition, are those who have fled the country of persecution.

The working group, nonetheless, decided that the task force should examine those designated classes, for several reasons. Designated class admissions are part of the overall government refugee statistics. Many within the class are, in fact, refugees. There are questions of consistency and equity that arise because of the existence of the classes - whether people from countries not part of the classes are being treated unfairly in comparison with those from countries within the classes.

Although the working group did not want the task force to examine inland processing, it did not want the task force to ignore it either. Inland processing serves as a useful point of comparison with overseas processing.

For all its faults, and we have to come to hear about these in great detail in the last little while, inland processing presents a number of features overseas processing lacks. There is an independent decision maker, independent from both the Department of Immigration and the Department of External Affairs. There is a right to make a claim. There is a right to an oral hearing. There is a right to counsel. At the credible basis stage one of the decision makers and at the full hearing stage both of the decision makers are expert in refugee law and country conditions. There is a right to an interpreter. There is a right to reasons for a refusal.

None of these features is present in the refugee selection system abroad. The issues of due process, fairness, natural jus- tice, and fundamental justice for overseas selection are part and parcel of what needs to be examined.

The focus of the task force will be on the Canadian selection system overseas. It is not meant to examine selection abroad generally. Nonetheless, here too, we do not wish to be overly restrictive. What other resettlement countries are doing in selecting overseas is a matter the task force must examine.

Canada has a reputation of snatching the best from the refugee settlement pool abroad. It would be worth while to examine how other resettlement countries manage to approach refugee resettlement with a more humanitarian and less utilitarian attitude than Canada.

Other countries will not, I expect, show up uniformly better than Canada. Here, as elsewhere in refugee protection, there will be common problems, common trends. The task force can perform a useful role by highlighting those trends.

The North/North grouping, gathering refugee NGOs from North America and Western Europe, met in Washington in June. The CCR delegation to that meeting added refugee selection abroad to the agenda of that meeting. The North/North grouping can be a useful source of information for the task force on this aspect of its work.

The working group, after settling on terms of reference, moved on to sources of information. One source the group is relying on is questionnaires. Anne Paludan of Edmonton has designed a questionnaire addressed to members of the Canadian Council for Refugees which was in the kits given to delegates at the CCR spring meeting. The questionnaire asks sponsorship groups in Canada to relate their experiences in sponsoring refugees through Canadian immigration offices overseas. Questions are asked about variation in processing time, access to lawyers and interpreters, equality of treatment. It is proposed that those Canadian Council members with more detailed knowledge of the application 
process abroad would be interviewed in a more detailed way. The questionnaire circulated in the kits is a preliminary questionnaire only.

There were a number of specific studies of the problem in particular areas of the globe and Canada on which the working group task force intends to draw. Noel Saint Pierre did a study of Chilean refugees applying from Argentina in 1987. Phil Ryan did a report for Dan Heap in July 1988 on the Canadian overseas selection of Central American refugees. Lisa Gilad, in a text she has written on the refugee experience in Newfoundland, dated November 1988, has a chapter with interviews of refugees in Newfoundland who record their experiences of Canadian processing abroad. The St. Barnabas Refugee Society in Edmonton is conducting a research project, scheduled for completion in December 1989, into refusal of Alberta applications for sponsorship of refugees from outside Canada.

The task force will draw on all sources of information that would usefully contribute to the study - the Government of Canada, the United Nations High Commission for Refugees, lawyers who work with refugee claimants and their families, and NGOs who assist refugee claimants abroad through the Canadian and other governmental refugee processing systems.

Regrettably, the Government of Canada is not interested in cooperating with this task force. I met with Gavin Stewart, the person in External Affairs responsible for visa offices abroad, and Joe Bissett, the Director of Immigration in Canada. In a letter to me dated April 5, 1989 , Joe Bissett, on behalf of both departments, wrote, "I regret that I can agree with neither your estimate of the need for such a task force, nor with the fundamental premises of your recommendation."

When I met with Gavin Stewart and Joe Bissett, I pointed out that Bill C-55 provided for a safe third country system. The Government had coined and pushed the term "irregular movements", referring to spontaneous asylum seekers. The Government agenda was to have refugee claimants processed from above, rather than through the claims system in Canada, by denying access to the claims system in Canada of anyone who had passed through what the government says is a safe third country.
Barbara McDougall, the Minister of Immigration, has overruled this agenda of the bureaucracy, announcing that no countries would be put on the safe third country list. The bureaucracy, nonetheless, continue to lobby for a safe thind country list. Even without it, the degradation of procedural protection in Canada under the new system makes the system of processing abroad all that much more important.

Despite the denial of the right to counsel of choice, the burden of proof in the refugee claimant, the absence of an appeal on the courts, the absence of an appeal as of right, the inability to stay in Canada even during limited technical applications for leave to appeal, the adversarial nature

\section{Under the} present system ... mistakes are easy to make, impossible to correct, and catastrophic once made.

of the credible basis hearing, the lack of independence of the adjudicator, one of the refugee decision makers at the credible basis stage, from immigration considerations and other problems besides, Bissett refused to acknowledge any problem in the current inland processing system at all. Under the present system, as we are finding day after day, mistakes are easy to make, impossible to correct, and catastrophic once made. What Bissett said to me that was "I do not agree that Canada's new refugee determination system denies protection to genuine refugees."

Bissett stated that there is "no obligation in law, domestic or international, to accept refugees abroad as immigrants in Canada, or to facilitate their admission to claim or obtain protection here." One component of the task force work would be to examine the legal obligations involved in helping refugees abroad. I will anticipate that report, at least in brief, by pointing out that there is a legal obligation at international law to share the world's refugee burden. There is an obligation at Canadian law to treat each refugee claimant who applies to come to Canada fairly and equitably.

Bissett adds "I could go on to criticize other aspects of your proposal specifically the unfounded allegations regarding the independence in decision making and the level of training of our officers abroad, but I do not believe this is necessary". It is perplexing to read the Government assert that its own officials are acting independently from the Government. One of the concerns that has been expressed about the visa selection process abroad is that visa officers act like unguided missiles acting on whim and caprice, shooting off in every and any decision. Bissett fails to draw the obvious conclusions from his confirmation of this problem.

In terms of the level of training of officers, I can report that this spring, when some visa officers were being brought in to Canada for meetings and briefings, I asked if the Canadian Council for Refugees could meet with the officers to talk with them about the processing of refugee claimants abroad. The answer the Council got back was that the visa officers were too busy.

These refusals do not mean no government officials will talk to the task force at all. Past studies have shown individual officers have been willing to cooperate on the basis of confidentiality. What this stonewalling demonstrates is that the Government itself will not do the study the task force proposes to do.

What is the purpose of the task force? It is two-fold. One is consciousness raising. The refugee selection process abroad presents a whole host of nightmarish problems that make the claims system in Canada appear benign by comparison. Yet because the victims of the system are left abroad there is very little awareness in Canada of the horrors of the system. The victims, in a foreign country, speaking a foreign language, without access to Canadian media, or Canadian courts, cannot make their victimization known. There is little they can do to remedy their mistreatment. The task force would speak for these people who cannot speak, provide a platform in Canada so that Canadians can find out what its officials are doing abroad to 